\title{
Marketing performance measurement: Directions for development
}

\author{
RECEIVED: 15 MARCH, 2000 \\ Michael J. Thomas \\ Professor of Marketing, University of Strathclyde, Stenhouse Building, \\ 173 Cathedral Street, Glasgow G4 ORQ \\ Tel: 0I4I 552 4400; Fax: 0I4I 552 2802; e-mail: michaelt@market.strath.ac.uk
}

\section{Abstract}

Just what constitutes 'added value'?' Can it be measured? Does marketing create transformations that accountants find difficult to grasp, so-called 'meta-values'?'

As we contemplate the future of the marketing profession, in a developing environment where marketing silos (departments) may cease to exist, ${ }^{3}$ and where IT offers unparalleled opportunities to access data, we need to be concerned that the reputation of marketing departments as big spenders with low accountability does not infect the reputations of marketing professionals. This paper is presented in the hope that it will stimulate researchers to continue to search for the Holy Grail of accountability. The paper explores some of the marketing accountability problem. It will offer some suggestions as to how a mix of financial, operational and intangible measures can be developed. The paper will suggest that current financial reporting methods are out of step with the times, and will propose how corporate reporting might develop systems that truly reflect the values of the company, reporting systems which give some real insights into stakeholder values, and how marketing investment and marketing skills contribute to these values.

\section{INTRODUCTION}

This paper reflects the author's concern with the gap in understanding and culture that exists between marketing directors and finance directors. The future of the marketing profession, to a degree, depends on the closing of this gap. A report 'Marketing Effectiveness' by management consultants KPMG and the Institute of Practitioners in Advertising (IPA) highlights this concern. Undertaken in 1996, on the basis of a survey of 100 finance directors drawn from the Financial Times Top 1000 companies, the report states:

'When asked to rate their marketing colleagues' financial literacy on a scale of nought to ten, the 100 Finance Directors, on average, awarded an unflattering score of 5.2; marketing lagged behind training, IT, human resources and $\mathrm{R} \& \mathrm{D}$ in the Financial Directors' analysis of what constitutes "necessary spend", and more than a quarter of Finance Directors (28\%) said they would cut marketing spend ahead of other activities if business costs were under
Michael J.

Thomas was appointed Professor of Marketing at Strathclyde University in January 1987. He is a consultant to the Know-How

Fund (British overseas aid programme) and the UN

Development Programme. He is particularly interested in the future of the marketing profession and the role of marketing in economic development. He is the author of a range of marketing books. 
pressure ... It is vital that the effectiveness of marketing becomes more transparent ... the gap between marketing and finance is a direct consequence of the failure in the past of the marketing and advertising world to get their minds around the discipline and thought processes of the financial community. ${ }^{4}$

Three further quotations:

'Company reports in the UK and the USA fail to give a true and fair picture of a company's position, because there is no requirement to disclose intangible investments like advertising, $\mathrm{R} \& \mathrm{D}$, training, innovation and customer relationships. It is ridiculous that companies can cut spending on such intangibles, and then report artificially inflated short-term profits, while stripping the long-term value of their customer equity. Ironically, the purpose of such exercises is usually to increase a company's stock market valuation. $^{5}$

'Unfortunately many organisations espouse strategies about customer relationships, core competencies, and organisational capabilities while motivating and measuring performance only with financial measures. ... in the short-term, the financial model reports ... spending cutbacks as increases in reported income, even when the reductions have cannibalised a company's stock of assets, and its capabilities for creating future economic value.'

'The generally accepted accounting principles ... don't allow for some of the prime drivers of corporate success - investments in intangible assets such as know-how, brands and customer loyalty." $^{7}$

\section{THE PROBLEMS OF MEASUREMENT}

Two terms must inform the debate about marketing performance measurement, efficiency and effectiveness.

Efficiency measures the relation between inputs and outputs. Marketing efficiency is about improving the ratio between outputs and inputs.

Effectiveness relates outputs to the ends or objectives of the organisation.

'Effectiveness is the foundation of success - efficiency is the minimum condition for survival after success has been achieved. Efficiency is concerned with doing things right. Effectiveness is doing the right things. ${ }^{8}$

Thomas produced a comprehensive survey of marketing productivity assessment methods. " Thomas is an enthusiast for the contribution margin approach to marketing productivity. To improve marketing decisions it is necessary to relate demand generating marketing efforts directly to the gross 
margin produced by the marketing effort. Contribution margin accounting can help the marketing manager to calculate marketing productivity ratios, so that the responsiveness of sales and profits can be directly related to marketing activities. Gross and net marketing earnings then become two focal points of control. Though this approach focuses primarily on product/product line profitability, calculation of average opportunity rates can enable marketing management to focus on those segments of the market where an opportunity for improving profit exists. Average opportunity rate is the measure of the profit-generating capability of marketing efforts in each segment of the business.

A series of measures can be used for processing marketing performance. They can be classified in this way:

- sales performance

- profit performance

- market share performance

- brand strength performance

- customer retention performance

- customer acquisition performance.

The first two performance measure types are traditionally the subject of financial reporting; characteristically these performance measures are hard values. The drivers of corporate success are not revealed in these hard values; however, intangible assets such as brands, market share, trade or buyers' franchises, sales networks, superior service skills, access to third-party resources (joint ventures and agreements), human resource skills, and research and development (R \& D) skills may be key factors in assessing an organisation's future capabilities.

\section{THE VALUE CHAIN}

Today, as transactional marketing gives way to relationship marketing, leadingedge companies see their primary mission as delivering value to customers. Marketing, uniquely in the company, business or organisation, manages the processes that deliver customer value; marketing therefore has the responsibility for, and must be held accountable for, the value added by that management task. It can be argued that the best players are delivering value to all stakeholders. What is needed are measures that provide insight into these capabilities. The architecture of such a value chain may be outlined. Table 1 attempts to portray this holistically, focusing on performance criteria. Table 2 outlines performance measures - other than marketing. ${ }^{10}$

The balanced scorecard approach clearly identifies the information that we should try to capture when measuring marketing performance. ${ }^{12,13}$ It looks at the added value chain from a different direction, based upon four penetrating strategic questions. All four questions are the responsibility of senior management. They explicate the leadership element of the added value chain in Table 1 . The questions themselves are not merely addressed to senior management, but to all cor- 


\section{Table 1}

THE ADDED VALUE CHAIN: PERFORMANCE CRITERIA ${ }^{11}$

Source of

added value Some performance criteria

Leadership $\rightarrow$ support for visions, goals, strategies

$\rightarrow$ ability to deliver customer value

Marketing $\rightarrow$ corporate brand position $\rightarrow$ customer satisfaction

Innovation $\rightarrow$ technology leadership $\rightarrow$ manufacturing learning

$\rightarrow$ product focus $\rightarrow$ time to market

Supply chain $\rightarrow$ scope of supplier/distributor network

$\rightarrow$ joint decision making $\rightarrow$ electronic data interchange $(\mathrm{EDI})$

$\rightarrow$ vendor managed inventory systems

Finance $\quad \rightarrow$ investor satisfaction $\rightarrow$ rankings $\rightarrow$ ratings

Employees $\rightarrow$ investments in people, competencies, relationship management motivation, empowerment

Community $\rightarrow$ handling of critical issues, confidence in organisation

porate employees, giving meaning to the concept that 'people are the corporate brand'. It is not possible to build a coherent corporate brand without the commitment of all employees.

The added value chain, and balanced scorecard are both methods for understanding and measuring the 'black box' of the value added by, and the potential and capability of marketing for, adding value in the future. The following equation (the black box) ${ }^{14}$ represents an algebraic expression of the challenge facing all modellers of the black box.

$$
\begin{aligned}
\mathrm{MP}= & \frac{\mathrm{RES} / \mathrm{EXP}}{\mathrm{SKL} / \mathrm{STR}} \\
& \times \mathrm{QCR} \times \mathrm{PTR} \times \mathrm{ENV}
\end{aligned}
$$

where

MP = Marketing performance or marketing productivity

RES $=$ Results

$\mathrm{EXP}=$ Management expectation (results must be weighted against management expectations)

SKL = Marketing employees' skills

STR $=$ Marketing structures within the company (information systems, databases, frontline information services, net-based marketing, new product development, order processing systems, planning systems and 
Table 2

THE ADDED VALUE CHAIN: PERFORMANCE MEASUREMENTS

Source of

added value Some performance measurements

Leadership support for basic values

speed to market

evidence of meta-values

$\mathrm{CV}=\frac{\text { Perception of benefits }}{\text { Costs of ownership }}$

Marketing see subsequent discussion

Innovation see subsequent discussion

Supply chain

supply costs

supply chain turnover/loyalty

distributor turnover/loyalty

EDI cooperation

distributor productivity

switching costs

Finance share price

relative cost of capital

ROE

shareholder value analysis

net profit

net profit as a $\%$ of turnover

capital expenditures

ROC

$\mathrm{P} / \mathrm{E}$ ratio

Employees value added per employee

employee turnover

employee satisfaction

long-term customer retention

employee satisfaction/customer satisfaction

'employer of choice' reputation

Community freedom to act

74 Journal of Targeting, Measurement and Analysis for Marketing Vol. 9, I, 70-91 (C) Henry Stewart Publications 0967-3237 (2000) 
Figure 1: The balanced scorecard as strategic management system

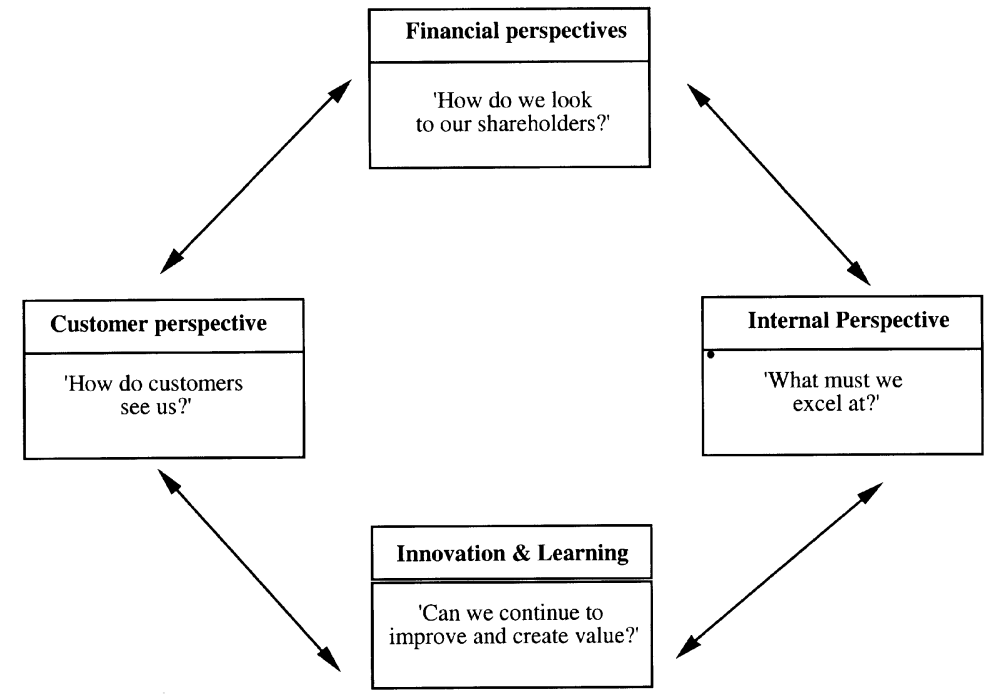

Source: Kaplan and Norton (1996)

processes, marketing policies)

$\mathrm{QCR}=$ Quality of competitive response (some measure of the toughness of competition)

PTR $=$ Quality of marketing partner response, ie providers of services to the firm and its customers, supply chain, distribution channels, service suppliers, advertising agencies, market research suppliers

$\mathrm{ENV}=$ Any and all environmental contingencies that might heighten or reduce marketing efforts, results or expectations.
Bonoma specifies the contents of the black box, and in the book provides case study illustrations of how the model can be made to work. $\mathrm{He}$ concludes

'the measurement, quantification and operationalisation implications of the model were pursued, and it was noted that, while measurement will be difficult, it is by no means impossible ... it is our view that researches into such thorny, complicated, and murky topics as marketing productivity analysis must be engaged with ever greater frequency in marketing, perhaps gaining in boldness what they lose in precision. The reason for this is 
Figure 2: The market as black box ${ }^{19}$

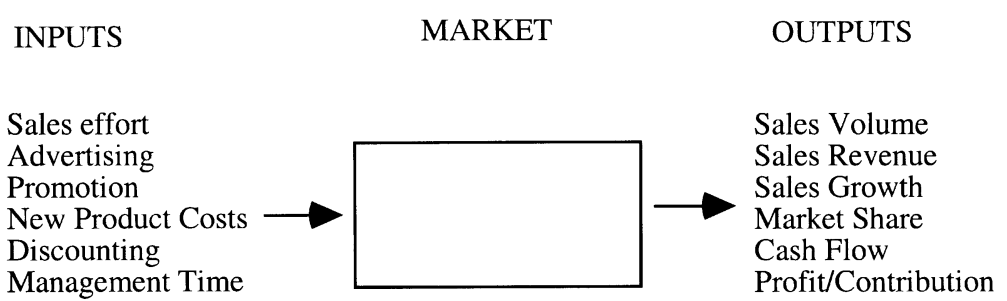

Source: Piercy, p477.

our more fundamental belief that marketing academics have allowed the rift in interests, relevance, and practicality that separates them from the managers their discipline claims to serve to become a veritable chasm. It is important to build bridges continually, not only because the discipline is intended to serve and advance management practice, but because it is often the case that the best practice outstrips theory, making the practitioner of the best "colleges" in which the academic can matriculate.'

That statement remains as powerful in 1998 as it was in 1988. That position informed the decision taken by the Chartered Institute of Marketing to sponsor, through its own charitable trust, a series of research undertakings focused on the contribution of marketing to business success. ${ }^{16,17}$ The methodology of the first two pieces of research will be described briefly. Before doing so, and to maintain a correct chronology, contributions from
Piercy and the British accounting profession are noted.

Piercy reminds us that 'As a way of keeping an eye on how things are going masses of ratios and cost analyses are fine. Where this goes wrong is when we forget the black box, when we come to interpret the results'. Piercy argues that the black box intervenes between inputs and outputs making it impossible for us to know which inputs achieved or created which outputs. ${ }^{18}$

He believes that something intervenes between input and outputs, that we really do not understand what it is, but nonetheless it prevents us from interpreting cause and effect. No claim here to scientific objectivity. Piercy argues that marketing information is always contaminated, being used to build a picture of the world that we all accept and assume to be true. The people who control that picture control much more besides. Though very postmodernist in tone, it is a somewhat discouraging viewpoint, for it argues that while the relationship between inputs and outputs may be 
predicted, we do not know why it happens. Marketers must surely claim knowledge of why the outputs are what they are.

The Institute of Chartered Accountants of Scotland issued a report entitled 'Measurement - The total picture ${ }^{20}$ in which they encouraged companies (and their own profession) to be concerned with something beyond traditional financial measures of performance; they were anxious to define the key performance measures that would yield the total picture of a company's achievements. Though the report looks both at the planning process and at monitoring performance, it is the latter which is of concern in this paper.

The report, under the subject marketing, offers a significant number of ratios, under the subheadings marketing, selling and distribution (see Appendix 1). Most of the ratios will probably be familiar. Such ratios focus only on efficiency, paying no heed to effectiveness.

The Cranfield Report undertaken by Cranfield School of Management was entitled 'Marketing, the challenge of change'. ${ }^{21}$ The research was sponsored by the Chartered Institute of Marketing (CIM). It reported on

the growing use and importance being given to performance measurement and monitoring. This is beyond doubt, a feature associated with leading companies. The number and scope of performance measures are growing, as companies establish and pre-tune the measures they need to take in order to deliver customer satisfaction end to end [emphasis added]. The measures are not restricted to assessing customer satisfaction levels, but increasingly, are becoming more sophisticated to cover the whole value chain, including internal customers. In the industrial sector, there is, generally, more reliance on the vendor analysis and league tables, provided by their customers, than on self derived measures.'

Thus, the Cranfield Report focuses entirely on customer-based measures of performance.

The Bradford Report, commissioned by CIM in 1995, was entitled 'Manufacturing - the marketing solution', with the subtitle 'Benchmarking marketing contributions to competitive manufacturing'. The Report discusses a wide range of soft measures (see Appendix 2), but relied on only two hard measures:

- profit before interest and tax to sales turnover

- profit before interest and tax to capital employed.

'Business success can be measured in tangible financial terms such as return on sales or capital employed. It can also be measured in an indirect way. Levels of customer satisfaction, employee and supplier commitment are also valid importance measures. Performance is the capability of the company to 
manage the overall process, or individual component, typically rated against external benchmarks [emphasis added]. ${ }^{23}$

A contribution to the debate appears in Marketing Management, the American Marketing Association's magazine directed at practitioners. Sheth and Sisodia state:

'There is so much to be gained from improvements in marketing productivity that even imperfect measurements can be of great value. However, we must measure the right things ... traditionally, productivity has been measured in terms of the quantity of output for a given quantity of input. However, such measures are unsatisfactory in that they fail to adjust for changes in the desirability of output... We suggest that marketing productivity be defined as the amount of desirable output per unit of input; in other words, output should be measured in terms of quality as well as quantity ... Ultimately the desired output of marketing can be stated in simple terms; acquiring and retaining customers profitability. A good measure of marketing productivity, therefore, must include the economics of customer acquisition and retention. ${ }^{24}$

Sheth and Sisodia recognise that quality as well as quantity should be measured, and their last phrase ('a good measure of marketing productivity') puts produc- tivity measurement out of the black box and into the customer-driven marketplace. Effectiveness and efficiency impact can be measured in the ways suggested in the top right quadrant of the model shown in Figure 3. They provide some quite specific tools for productivity analysis, which are worth citing. The last five items in the quadrant are capable of quantitative analysis. Four of those items are defined below and the fifth, the re-engineering marketing process, is summarised in Table 3. (The right-hand column focuses on information technology, identifying the new tools that IT is placing at the marketer's disposal.)

- market response modelling: use well-established marketing models when high-quality data are available. They press their case for using Assessor (new brand share predictor), Call Plan (optimal salesforce size and predictor) and Mediac (media selection, scheduling and budgeting)

- database modelling: databases of high quality are now becoming available, improving customer response rates way above the 1-2 per cent rates resulting from junk mailings. Marketing effort can be more precisely targeted and create additional customer value

- front-line information services (FIS): FIS must be given the priority that is usually reserved for MIS. FIS promotes efficiency through faster and more accurate processing of customers' orders, and effectiveness 
Figure 3: Classifying approaches to improve marketing productivity

\begin{tabular}{|l|l|}
$\begin{array}{l}\text { Effectiveness } \\
\text { impact }\end{array}$ & $\begin{array}{l}\text { Dynamic Pricing } \\
\text { Activity-based costing } \\
\text { Zero-based budgeting } \\
\text { Adjusting compensation of } \\
\text { marketing personnel } \\
\text { Continuous assessment of } \\
\text { marketing practices }\end{array}$ \\
\hline
\end{tabular}

Partnering

Relationship marketing

Insourcing vs. outsourcing

Customers in the value chain

Market response modeling

Data-base marketing

Front-line information systems

Net-based marketing

Re-engineering marketing

Marketing alliances

Reducing product and

attribute proliferation

Umbrella branding

Rethinking advertising

Focusing promotions

Unbundling \& rebundling

services

Efficiency Impact

by improving the quality of service received by the customer

- Internet-based marketing (NBM): marketing has a great deal riding on the information highway - it should provide new forms of customer-company, and customer-customer communication, and new opportunities for value creation. NBM should be a mode of marketing that is cost-effective, accountable, individualised, interactive and relationship based.

Marketing is, as Sheth and Sisodia state, 'about pleasing (even delighting) the customer to such an extent that he or she is willing, even anxious, to engage in a continuous relationship with the seller. Incessant pressures to increase marketing efficiency without regard for marketing effectiveness can, however, easily lead to customer alienation, rebellion and ultimately defection. ${ }^{25}$

With this discussion as background, the author has been encouraged to develop the arguments further. What follows is a model for measuring marketing performance, an attempt to embody the threads of the discussion so far.

\section{A NOTE ON MARKET SHARE}

First, a note on market share. Widely used as a proxy for performance, it hides more than it reveals, as Figure 4 demonstrates. $^{26}$

The author does not pretend that he has cracked the problem of the black box. Measuring marketing outputs is 
Table 3

\section{RE-ENGINEERING'S EFFECT ON KEY MARKETING PROCESSES}

\begin{tabular}{|c|c|c|c|}
\hline Process & Problem & Nature of rethinking & IT enablers \\
\hline $\begin{array}{l}\text { New product } \\
\text { development }\end{array}$ & $\begin{array}{l}\text { Slow, costly, too } \\
\text { much iteration, } \\
\text { results in products } \\
\text { lacking 'integrity' }\end{array}$ & $\begin{array}{l}\text { Involve marketing, } \\
\text { manufacturing, } \\
\text { design and so on } \\
\text { in a platform team } \\
\text { from day one; } \\
\text { facilitate } \\
\text { communication } \\
\text { among them } \\
\text { through technology }\end{array}$ & $\begin{array}{l}\text { CAD/CAM, photo } \\
\text { realistic } \\
\text { visualisation, } \\
\text { groupware, } \\
\text { holography, } \\
\text { videoconferencing }\end{array}$ \\
\hline $\begin{array}{l}\text { Order } \\
\text { management }\end{array}$ & $\begin{array}{l}\text { Expensive, slow, } \\
\text { frequent errors }\end{array}$ & $\begin{array}{l}\text { JIT marketing, } \\
\text { automatic } \\
\text { replenishment, } \\
\text { vendor managed } \\
\text { inventory, virtual } \\
\text { inventory, } \\
\text { partnership, } \\
\text { cross-docking }\end{array}$ & $\begin{array}{l}\text { EDI, POS } \\
\text { terminals linked to } \\
\text { vendor, } \\
\text { bar-coding, expert } \\
\text { systems, locational } \\
\text { systems }\end{array}$ \\
\hline $\begin{array}{l}\text { Customer } \\
\text { retention/ } \\
\text { relationship } \\
\text { management }\end{array}$ & $\begin{array}{l}\text { High churn, } \\
\text { deal-prone } \\
\text { customers, focus } \\
\text { on last transaction, } \\
\text { no learning }\end{array}$ & $\begin{array}{l}\text { Lifetime revenues, } \\
\text { win-win } \\
\text { relationships, } \\
\text { process and goal } \\
\text { convergence }\end{array}$ & $\begin{array}{l}\text { Linked information } \\
\text { systems, database } \\
\text { marketing, mass } \\
\text { customisation }\end{array}$ \\
\hline
\end{tabular}

not easy. $\mathrm{He}$ is, of course, aware that what marketing effort achieves is the result of multi-factor influences. The 17 revolution provides marketers (and others) with an opportunity to mine data that may reveal multi-factorial relationships. What he has done is describe a set of marketing relationships in terms of inputs and outputs (recognising that marketing does not necessarily control all the inputs nor all the outputs). He hopes, however, to open up the black box, if only to encourage others to pursue a model that is both predictive and descriptive. Some will argue that marketing outcomes are not a proxy for company performance as a whole. That is a philosophical argument that awaits another paper. 


\section{Figure 4}

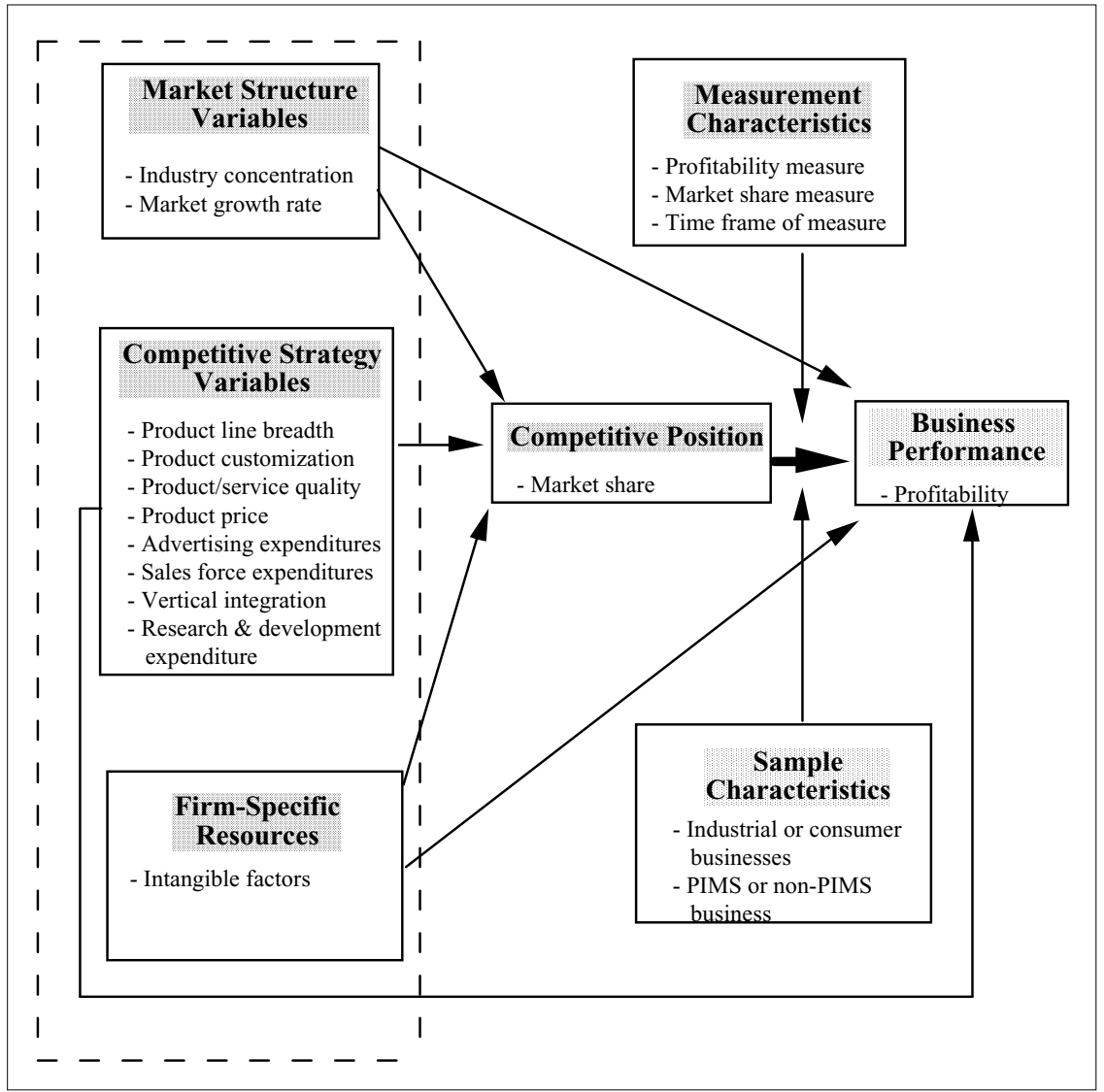

Source: Szymanski (1993)

Although business performance and competitive position can be measured by profitability and market share within a time frame, performance measurement needs to engage the detail underlying these proxy measures.

\section{THE NEED FOR MORE SOPHISTICATED MEASURES}

Best of class research done on Japanese companies $^{27}$ has revealed consistency in using the following measures:

- product and/or service quality (do I get what I wanted?)

- delivery/timeliness quality (did I get it when I wanted it?)

- cost effectiveness (did I get it at a price that, when combined with the first two, created a perception of high value?) 
- employee morale (is any organisation stable and growing in capability?); and

- are the people engaged in improving customer satisfaction and value in a systematic way?

- employee safety and health (am I demonstrating commitment and concern to any people about their importance to the organisation?)

Clearly these measures go beyond the competitive strategy variables in Figure 4 , and demonstrate that both customers and employees are critical to measuring marketing performance.

In this paper we want to explore a wider range of performance measures focused primarily on brand strength performance, customer retention performance, and customer acquisition performance. We may then return to market share performance measures, as a means of capturing the values implicit in the equation. The notation for hard value (HV) suggests relatively easy measurement, soft value (SV) suggests measurements that will not be immediately recognised by the accounting profession, but which have been designed, developed and applied by market researchers.

\section{HOW ARE PROCESSES MEASURED?}

The challenge is to measure the values added and the meta-values created by the processes for which marketing management has responsibility. Figure 5 portrays these processes. $^{28}$

\section{PROPOSALS FOR MEASUREMENT OF PROCESSES}

The brand development process and brand strength performance

That brand development holds the prospect for creating brand equity is uncontested. How brand equity generates added value is clearly illustrated in Figure 6. ${ }^{29}$ The challenge is to develop measures that capture these values. The following measures are relevant:

1A (HV) Brand market share

1B (HV) Distribution/price index

1C (SV) Brand awareness index

1D (SV) Perceived quality

1E (SV) Perceived value

$1 \mathrm{~F}$ (SV) Brand personality

$1 \mathrm{G}$ (SV) Price premium (relative price vs. market average)

$1 \mathrm{H}$ (SV) Satisfaction/loyalty measures

1J (HV) Brand value.

These measures should illuminate the brand development process, define precisely the corporate brand position (either solus or as the sum of individual brand performances) and measure the level of customer satisfaction associated directly with the brand.

The issue of brand valuation is currently a very lively one, with the report of the Accounting Standards Board (UK) now available. There is still concern that the debate is too narrowly focused, too concerned to develop a system compatible with current accounting practices. It is clear that of the nine new areas of perfor- 
Figure 5

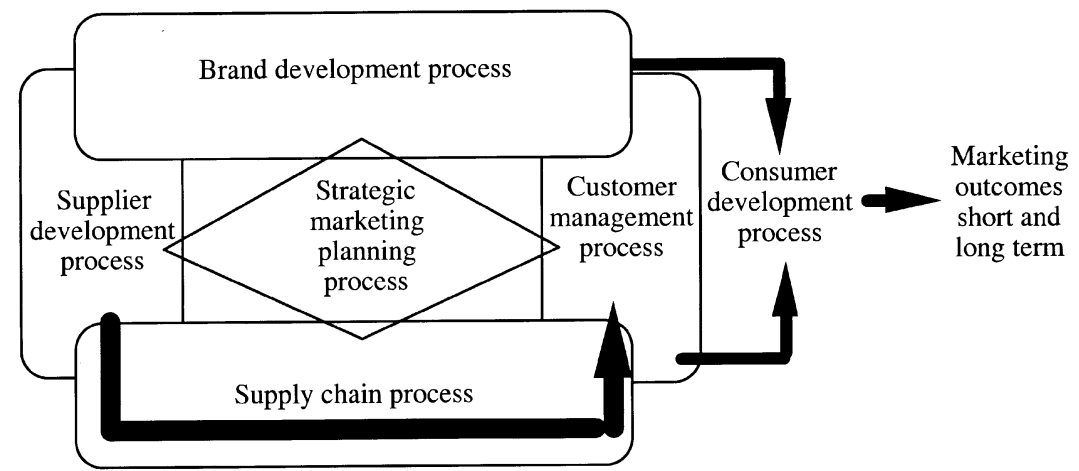

Source: After Christopher (1996)

mance identified above, three only are designated hard values, and IJ, brand value, may still conceal more than it reveals. The purpose of this paper is not to address this particular issue in detail. It is necessary to develop a set of performance measures that illustrate the complexity and multifaceted nature of brand performance, that illustrate the web of dependency effects. An attempt has been made to categorise the process. See Figure 7. The source for the figure is Egan and Guilding ${ }^{30}$ who argue that this process categorisation yields a typology that offers a number of benefits, some of which include the typology's inclusion of the value creator category, ignored by traditional accounting practices. Marketing assets are similarly ignored by traditional accounting procedures, and value manifestation which can be measured, but traditionally is ignored.
The importance of the brand valuation debate cannot be over-emphasised since the appearance on the balance sheet of a brand value will be the first step towards recognition of what has hitherto been a soft value in the eyes of the accounting profession..$^{31,32}$

The customer management process and customer retention performance

The following measures appear to be relevant:

2A (SV) Satisfaction index (relative to competitors)

2B (SV) Security of share/retention \%

2C (SV) Sales predictability

2D (SV) Complaint index

2E (SV) Inquiry share

2F (HV) Sales revenue

2G (HV) Sales volume

$2 \mathrm{H}(\mathrm{HV})$ Sales growth 
Figure 6

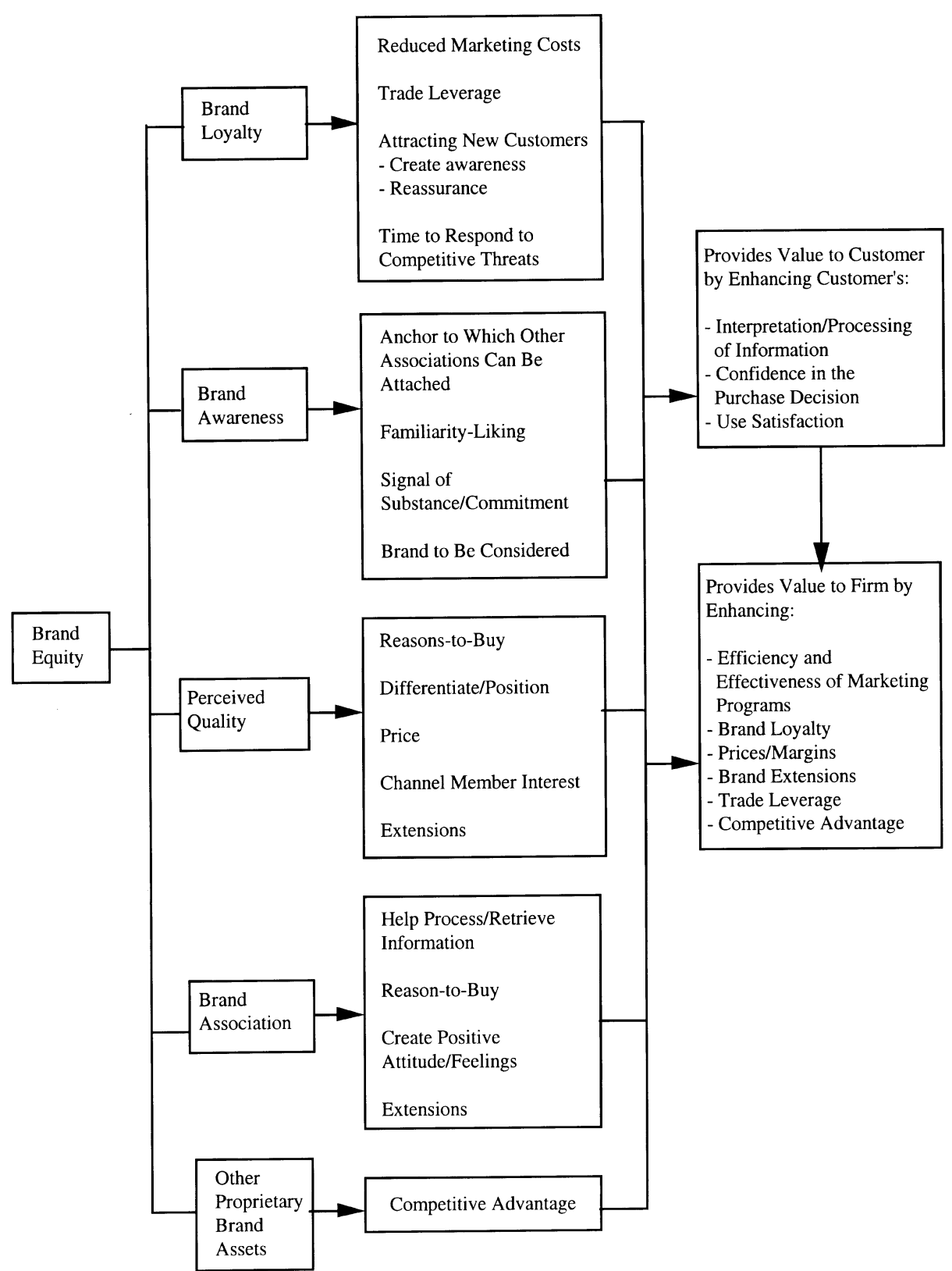

Source: Aaker (1996). 
Figure 7: Brand value budgeting: process categorisation Marketing Asset Typology $\quad$ Accounting Issues

Value_creator

eg. advertising, product

development, trade support

Expense or capitalise
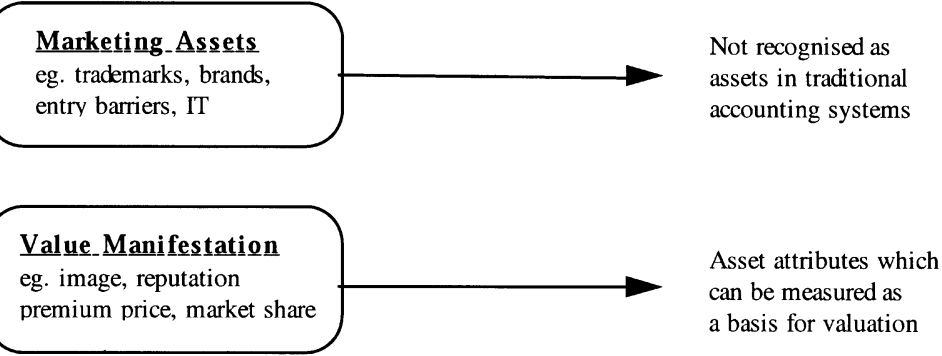

Marketing Asset

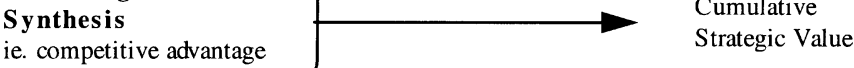

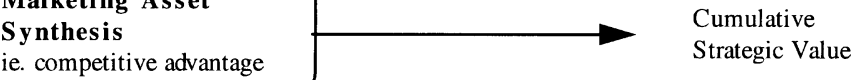

2I (HV) Cash flow

2J (HV) Profit contribution: by product; by customer: by sales outlet.

\section{The customer development process}

This process encompasses both current customers and products (and services) and potential customers. It is thus an umbrella for measuring innovation performance.

3A (HV) Investment/sales

3B (HV) \% of products equal to $80 \%$ of sales

3C $(\mathrm{HV}) \%$ of products $>5$ years old
3D (SV) Time to market (by product)

3E (SV) Innovation in progress.

\section{Marketing outcomes}

To complete the system of performance measurement we may return to what are arguably a set of hard values which may be seen as measures of marketing outcomes.

4A (HV) Market share, by market, by region

4B (HV) Competitors' performance measures

4C (SV) New markets entered (in period $n$ ) 
4D (HV) $\mathrm{ROS}=$ operating profit as a $\%$ of revenue

4E (HV) ROI

$=$ profits/investment

$=$ profit $/$ sales $\times$ sales/investment

$=\operatorname{ROS} \times$ asset turnover ratio

$=\operatorname{ROS} \times 1$ [investment/sales]

$=\operatorname{ROS} \times 1 /$ investment intensity

4F (HV) ROE

$=$ profits/shareholder equity

$(\mathrm{SV})=\mathrm{ROI} \times$ financial leverage.

\section{CONCLUSIONS AND \\ RECOMMENDATIONS FOR FURTHER RESEARCH}

All of the above measures, brand strength performance, customer retention performance, customer acquisition performance, and marketing outcomes attempt to capture the marketing and innovation streams in the Added Value Chain (Table 1). Any discussion of these measures must refer to the failings of current financial accounting approaches.

Current approaches fail to recognise intangible assets (meta-values) and their impact on future revenue. It is necessary to develop a measurement system that does not ignore advertising, R\&D, core marketing competencies, new product development, market knowledge and customer relationships.

'There is an urgent need at the very least for very soft data in company accounts on intangibles such as skills and capital. For while managers consistently proclaim that people are the company's most valuable resource, their actions are heavily influenced by accountancy which treats people as costs, not assets. ${ }^{33}$

Current financial accounting focuses on 'real assets', namely buildings, equipment, cash etc., but fails totally to address brand strength and loyalty, distributor goodwill, market share and trends, relative pricing, customer retention, and confidence in the company and its leadership.

Perhaps most of all current approaches fail to answer any of the 'why' questions. The brand valuation debate, which is currently being pursued vigorously (at least in the UK), is critical to the development of this dialogue. ${ }^{34}$

The argument is sometimes heard that IT systems now produce the problem of too many performance measures. What is proposed is not too complicated and, with imaginative presentation, such measures could be easily assimilated and become an integral part of strategic process thinking. It is not hard to conceive of them becoming part of the annual corporate reporting process, and many of these measures might be exposed as material to support the balance sheet.

What is proposed here is not intended to replace the presentation of annual accounts according to generally accepted accounting principles. My view is that the annual report should be a source of insight into a company's ability to deal with the vicissitudes of 
the future, as well as a report on performance over the last financial year. The measures advocated here could form an appendix to the visual presentation of accounts. (This is already done by a number of Swedish companies.) Given the situation of the market capitalisation of many (Internet) companies, it is perfectly obvious that current financial reporting is no basis for understanding capitalisations that are focused on the medium term. The author's advocacy of hard and soft measures would require companies to reveal what might be otherwise concealed, and provide a more rational basis for assessing future performance capability. The format advocated is revealed to meetings of financial analysts - why should it not be revealed to the under-investing public?

Finally, returning to the performance measurement equation, it may be observed that this set of measurements captures, to a degree, the relationships described in the equation. Further work needs to be done to elaborate the terms QCR, PTR and ENV in performance terms. Further research is needed to define and measure the contribution of marketing skills and activities to the long-term viability of a company or organisation. The author believes that his proposal addresses the architecture of a reporting system that could eventually be incorporated as part of the annual company report, so as to enable stockholders to understand fully a company's capability to survive and prosper into the future. More importantly, this architecture provides marketing managers with the means to argue their corner with company accountants. It is the beginning of a critical dialogue.

\section{ACKNOWLEDGMENTS}

The author is grateful to Helene Broman, Broman Leadership and Communications Stockholm, and to Douglas Park, Systems for World Class Competitiveness, Boise, Idaho, for comments on earlier drafts of this paper.

\section{REFERENCES}

1 Added value: a working definition is that added value is 'a sum of money which represents the transformation of a product or service characteristics as a result of organisational activities', Wood, L. M. (1996) 'Added value: Marketing basics', Journal of Marketing Management, Vol. 12, p. 742.

2 Meta-values are assets the company really owns without being able to account for them with traditional methods. Linn, E. (1996) 'Market dynamics', (2nd ed.) Meta Management AB, Stockholm, p. 30ff.

3 See Thomas, M. J. (1996) 'The changing nature of the marketing perspective', Chapter 9 in Shaw, S. A. and Hood, N. (1996) 'Marketing in evolution', Macmillan, London, pp. 190205.

4 IPA and KPMG (1996) 'Marketing effectiveness', a survey of financial directors, London and 'When a tightwad meets an illiterate', Accountancy Age, 28 
November, 1996, pp. 14-16.

5 Davidson, H. (1997) 'Even more offensive marketing', Penguin Books, London pp. 61-62.

6 Kaplan, R. and Norton, D. (1996) 'Using the balanced scorecard as a strategic management system', Harvard Business Review, Jan./Feb., pp. 75-85.

7 Professor Baruch Lev, Professor of Accounting at New York University as quoted in Davidson (1997) op. cit., p. 64.

8 Drucker, P. (1974) 'Management: Tasks, responsibilities, practices', Harper and Row, New York.

9 Thomas, M. J. (1984) 'The meaning of marketing productivity analysis', Marketing Intelligence and Planning, Vol. 2, No. 2, pp. 13-28.

10 These ideas are more fully developed in Broman, H. and Johnsson, H. V. A. (1996) 'Return on communications', Swedish Public Relations Association, Stockholm.

11 The architecture of the value chain and some of the ideas presented in Tables 1 and 2 are the work of Helene Broman, to whom I am indebted; see pages 16 and 29 in Broman and Johnsson, ibid.

12 Kaplan, R. and Norton, D. (1992) 'The balanced scorecard - measures that drive performance', Harvard Business Review, Jan./Feb., pp. 71-79.

13 Kaplan and Norton (1996) op. cit.

14 After Bonoma, M. T. A. and Clark, B. H. (1988) 'Marketing performance assessment', Harvard Business School, Cambridge.

15 ibid., pp. 107 and 109.

16 Chartered Institute of Marketing
(1994) 'Marketing, the challenge of change'.

17 Chartered Institute of Marketing (1995) 'Manufacturing — The marketing solution'.

18 Piercy, N. (1992) 'Market-led strategic change' (2nd ed.), ButterworthHeinemann, Oxford, pp. 475-489.

19 ibid., p. 477.

20 Chartered Accountants of Scotland (1993) 'Measurement — The total picture'.

21 Cranfield School of Management (1994) 'Marketing, the challenge of change' (the Cranfield Report), p. 109.

22 Bradford Report (1995) 'Manufacturing — the marketing solution'.

23 ibid., p. 49.

24 Sheth, J. N. and Sisodia, R. (1995) 'Feeling the heat - Part 1', Marketing Management, Vol. 4, No. 2, p. 11.

25 Sheth, J. N. and Sisodia, R. (1995) 'Feeling the heat - Part 2', Marketing Management, Vol. 4, No. 3, p. 30.

26 The source of the figure is Szymanski, D. M., Bharadwaj, S. G. and Varadarajan, P. R. (1993) 'An analysis of the market share-profitability relationship', Journal of Marketing, Vol. 157, pp. 1-18.

27 The author is grateful to Douglas Park of Systems for World Class Competitiveness, Idaho, for this information.

28 After Christopher, M. (1996) 'From brand value to customer value', Journal of Marketing Practice, Vol. 2, No. 1, pp. 55-66.

29 Source Aaker, D. A. (1996) 'Building strong brands', The Free Press, Glencoe, p. 9.

30 Egan, C. and Guilding, C. (1994) 
'Dimensions of brand performance: Challenges for marketing management and managerial accountancy', Journal of Marketing Management, Vol. 10, p. 465.

31 Wood, L. M. (1995) 'Brands: The Asset Test', Journal of Marketing Management, Vol. 11, pp. 547-570.

32 Wood (1996) op. cit. (Ref. 1).

33 Plender, J. (1997) 'A stake in the future', Nicolas Brealey, London, p. 73.

34 See Thomas, M. J. (1998) Journal of Brand Management, Vol. 5, No. 5, Special Issue on Brand Valuation, pp. 222302.

35 Institute of Chartered Accountants, Scotland (1993) 'Measurement — The total picture'.

36 Thomas (1998) op. cit.

\section{APPENDIX 1}

\section{Marketing}

Marketing

contribution/marketing assets

Marketing costs/sales

Sales/marketing assets

Market research costs/sales

Advertising costs/sales

Promotion costs/sales

Selling costs/sales

Discount/sales

Sales office costs/sales

Sales office costs/number of orders or invoices

Sales/number of orders or invoices

Bad debts/sales

Warehouse costs/sales

Selling and distribution vehicles/sales

Finished goods stock/sales

Finished goods stock/average daily production of goods sold

Debtors/sales

Debtors/average daily sales

\section{Selling}

Selling costs/sales

Sales by rep/total sales

Rep remuneration and exp/sales by reps

Sales by agent/total sales

Agents commission/sales by agents

Selling office costs/sales

Call success rate

Average cost of a call

Average value or order

\section{Distribution}

Distribution costs/sales

Miles/sales

Distribution costs/miles 


\section{APPENDIX $2^{36}$}

\section{COMPONENTS OF THE MARKETING EXCELLENCE FRAMEWORK}

Marketing strategy

Quality strategy

Innovation

Customer development

Branding
There is an extensive awareness of the need for external analysis and review of the company's competitive and market position

There is a systematic process for the collection and use of marketing information

Staff at all levels are actively involved in the collection of market information

There is a well-defined strategic marketing planning process

There are explicit strategies for developing and managing strategic alliances Resources are explicitly developed by reference to competitive information Organisation structures reflect the marketing strategy

The company culture is marketing oriented

Top management is committed to quality

The company has a long-term commitment to improving quality

The company has a culture which underpins quality

The company uses systems, tools and techniques to monitor and control quality

New product development is seen as a critical business process Systematic approaches are used in new product development

External stakeholders are consciously and deliberately involved in new product development

Product and process development are simultaneous considerations

Cross-functional teams are consciously and deliberately involved in new product development performance

There is a conscious and explicit approach to segmentation, targeting and positioning

The company explicitly manages through relationship marketing

The marketing programme is regularly adjusted to reflect and anticipate customers' needs

The company has an explicit programme to develop strategic partnerships with distributors, agents and other intermediaries

There is a clear understanding of the role of brands throughout the business

Branding is seen as a source of strategic competitive advantage 
Appendix 2 continued)

\section{Supply chain}

management Supply chain management has a strategic role

There are explicit systems in place for managing suppliers

The company and its suppliers share the same strategic vision

Manufacturing's strategic role is explicitly recognised

Manufacturing Manufacturing investment is determined by explicit reference to market strategy needs and competitive strategy. 